\title{
TEST-RETEST RELIABILITY OF THE NET JOINT POWER TRANSFERRED BY THE LOWER LIMBS DURING WALKING IN HEALTHY MEN
}

\author{
Daniel Jandačka $^{1, *}$, Jaroslav Uchytil ${ }^{1}$, Zdeněk Svoboda ${ }^{2}$, Milan Elfmark², Miroslav Janura²
}

\author{
${ }^{1}$ Human Motion Diagnostic Center, University of Ostrava, Ostrava, Czech Republic \\ ${ }^{2}$ Faculty of Physical Culture, Palacký University, Olomouc, Czech Republic
}

Submitted in May, 2013

\begin{abstract}
OBJECTIVE: To determine the reliability of the measurement of net joint power during repeated gait measurements within one day and between two different measurement days.

METHODS: Thirty able-bodied men who underwent repeated gait measurements within a day and between days participated in this research. An acceptable trial was one in which the participant complied with the range of walking speed $1.45 \mathrm{~m} / \mathrm{s} \pm 5 \%$. Three-dimensional angles, angular velocities, net moments of force and net power for the ankle, knee and hip joints were determined using external passive reflective markers, an 8-camera motion analysis system and two force plates.

RESULTS: This study presents the patterns of the net power in the fundamental joints of the lower limbs in young healthy men at standard gait velocity. Intraclass correlation coefficients for net joint power measure reached values in the range of .70 to .89 on the first day, from .69 to .86 on the second day, and from .67 to .83 in total.

CONCLUSION: The reliability of the measurement of the peak net joint power within one day and between the two measurement days was evaluated as satisfactory. The study provides the value of minimal detectable change for the peak net power of the lower limb in the sagittal plane during gait. The net joint power appears to be a reliable measure and could be used in practice.
\end{abstract}

Keywords: Motion analysis, inverse dynamics, intraclass correlation, error of measurement, minimal detectable change.

\section{INTRODUCTION}

In advanced countries, gait analysis has become an integral part of the decision-making process for rehabilitation physicians, orthopedists and kinanthropologists. Nevertheless, the ability to detect real changes in gait biomechanics is limited by the methodology of data collection (Cappozzo, Croce, Leardini, \& Chiari, $2005)$ and by the natural variability of human movement (Bartlett, Wheat, \& Robins, 2007; Hamill, van Emmerik, Heiderscheit, \& Li, 1999). When walking, energy has to be absorbed and generated through muscle activity, and the mechanical output is thus transferred mainly by the lower limb joints. Net joint power is a complex quantity that incorporates information on kinematics and kinetics of human movement. Sadeghi, Allard, Prince, and Labelle (2000) describe net muscle power transferred by the lower limb joints during gait as a valuable indicator of the ability to accelerate the

\footnotetext{
* Address for correspondence: Daniel Jandačka, Human Motion Diagnostic Center, University of Ostrava, Varenská 40a, 70200 Ostrava, Czech Republic. E-mail: daniel.jandacka@osu.cz
}

human body and, at the same time, of the ability to control its stability. The net joint power of the lower limbs thus represents a useful value for evaluating correct gait function.

The net joint power of the lower limbs depends on gait velocity (Chen, Kuo, \& Andriacchi, 1997). Only the study by Wilken, Rodriguez, Brawner, and Darter (2012) has dealt with the issue of the reliability of peak net power measurements under monitored gait velocity in healthy subjects. Reliability values were in the good to excellent range. The measurements were carried out on 14 men and 15 women. When measuring net joint power in a mixed group, a certain degree of heteroscedasticity can be expected due to varying amounts of subcutaneous fat in men and women (Bazzocchi et al., 2012). Extensive subcutaneous fat and skin movements cause errors when taking measurements using the method of optoelectronic stereophotogrammetry (Leardini, Chiari, Croce, \& Cappozzo, 2005). Subsequently, the values of the intraclass correlation coefficient (ICC), or values pertaining to minimal detectable change or typical errors in measurement, can be distorted by the heteroscedasticity.

Describing net joint power in young healthy individuals is of importance, particularly because the val- 
ues measured in such individuals can be taken as the norm when evaluating gait dysfunction (Õunpuu, Davis, \& DeLuca, 1996) in young individuals with lower limb amputation (Svoboda, Janura, Cabell, \& Elfmark, 2012) or other pathological conditions such as Achilles tendon elongation (Jandačka, Zahradnik, Foldyna, \& Hamill, 2013). A pathological condition in the human motor system can be often demonstrated by a gait pattern which is unambiguously abnormal (Whittle, 2007). However, the database of normative reference data have to be created using the same methods as those used to acquire data from symptomatic subjects (Õunpuu, Davis, \& DeLuca, 1996). In addition, these reference values need to be accompanied by data on the reliability of the measurement, the estimation of sample size for further research studies, and the minimal detectable change for clinical practice. The first purpose of this study was to determine normative values of the net power transferred by the main lower limb joints during gait in healthy men. The main purpose of this study was to determine the reliability of the measurement of net joint power during repeated gait measurements within one day and also between two different measurement days.

\section{METHODS}

\section{Subjects}

More than 34,000 students from two universities were addressed via email, inviting them to participate in gait research if they considered themselves healthy. Subjects were only included in the research if they did not indicate current or previous muscular or skeletal disorders or diseases of the central nervous system; the sample was further restricted to include only non-smokers, those who consume alcohol not at all or only occasionally, and those who do not use any medication. Out of 100 students who expressed an interest, 50 subjects were finally selected who fulfilled all of the abovestated criteria; they then underwent the gait measurements. Out of these 50 subjects, 15 students came only once to the biomechanics laboratory and were thus excluded from further analyses. Kinematic data from 5 subjects were incomplete; they were also excluded from further analyses. The final research sample consisted of 30 men who underwent repeated gait measurements over two days. The characteristics of the male subjects were as follows - age $21.4 \pm 1.4$ years (mean \pm standard deviation); height $1.81 \pm 0.07 \mathrm{~m}$; mass $74.8 \pm 8.1 \mathrm{~kg}$; body fat $10.8 \pm 3.8 \%$; shoe size (European Union) $43.5 \pm 1.7$; body mass index $22.7 \pm 2.0 \mathrm{~kg} / \mathrm{m}^{2}$; physical activity (number of times per week engaging in active physical activity for a period of at least 45 minutes) $2.6 \pm 2.0$ times. The lower limb right/left dominancy ratio was $26 / 4$. The study report was approved by the
Ethics and Research Committee of the University of Ostrava. All subjects signed an informed consent form.

\section{Instrumentation}

Gait kinematics were recorded by means of 8 infrared cameras (Qualisys Oqus 100, Sweden, Göteborg). Ground reaction forces were measured with two force plates (Kistler 9286AA and 9286BA, Switzerland, Winterthur), which were camouflaged and embedded in the floor 10 meters from the start of the 16 meterlong walkway such that each subject trod fully with the right and left feet on one of these force plates. Kinematic and kinetic data were synchronized and recorded at $247 \mathrm{~Hz}$. The gait velocity was measured by two photocells located in such a manner that they read the average velocity of the body movement in the gait cycle, which started with the right heel touching the first force plate and ended with the right heel touching the surface. A bio-impedance device (TANITA, 418 MA, USA) was applied for measuring body composition.

\section{Protocol}

Each subject visited the biomechanics laboratory twice. Each subject first underwent measurement for body composition and was then given gait training in order to ensure that they would walk with the correct velocity and walk fully on the force plates. Subsequently, 19 $\mathrm{mm}$ diameter retro-reflective markers were placed on the subject's body by a trained and authorized expert. Some markers were used for tracking only, and other markers were used for tracking and calibration; the markers were located according to the recommendations of the Visual3D software (C-motion, USA, Germantown) - bilaterally on the head, vertically above the acromion in the sagittal plane above the eyes anteriorly, on the acromion, the iliac crest, the trochanter major femoris, the distal part of os metacarpi III, the processus styloideus radii, the processus styloideus ulnae, the epicondylus lateralis humeri, the epicondylus medialis humeri, the lateral part of the shoulder joint above the tuberculum maius humeri, the epicondylus lateralis femoris, the epicondylus medialis femoris, the malleolus lateralis, the malleolus medialis, the os metatarsi I, the os metatarsi $\mathrm{V}$, and on the calcaneus posteriorly. Subsequently, clusters of four markers on a rigid plate were located on the shank and the thigh, and clusters of three markers on a rigid plate were located on the upper arm and the forearm. Other tracking markers were located on the head, vertically above the acromion in the sagittal plane above the eyes posteriorly, on the sternum (xiphoid process), the 10th thoracic vertebra, the 7 th cervical vertebra, the posterior superior iliac spine, laterally on the calcaneus and caudally on the calcaneus. Than wand calibration method was used with L-shaped reference structure and a calibration 
wand. Subsequently, the positions of all markers were recorded with the subject standing in a natural upright posture in order to serve as a reference for calibration. After removing the calibration markers, the subject was asked to walk along the $16 \mathrm{~m}$ walkway and the measuring system recorded six valid attempts. An attempt was marked as valid if the gait velocity was within the range of $1.45 \mathrm{~m} / \mathrm{s} \pm 5 \%$, which is the standard walking speed of young and healthy individuals (Bartlett, Wheat, \& Robins, 2007; Kirtley, 2006), and if each lower limb trod fully with the entire foot on one of the floor-embedded force plates. All attempts were carried out barefoot. The same procedure for measuring gait biomechanics was carried out during the subject's second visit after one week. Additionally, the dominant lower extremity was determined by the test of targeted kicking of a ball (Seeley, Umberger, \& Shapiro, 2008).

\section{Data analysis}

Qualisys track manager software (Qualisys, Sweden, Göteborg) was used for the measurement. First, individual retro-reflective markers were identified. Kinematic and kinetic data in $\mathrm{C} 3 \mathrm{D}$ format were subsequently exported to Visual3D software (C-motion, USA, Germantown), where a model of the human body was created. The head and hands were modelled as spheres, the body as a cylinder and all other segments as right circular cones (Hanavan, 1964). For each subject, only three attempts from each testing day were analyzed, identifying all the tracking markers and the tracking/ calibration markers. Analog data were filtered using a low-pass Butterworth filter at $30 \mathrm{~Hz}$ frequency and the positions of the retro-reflective markers were filtered using a low-pass $6 \mathrm{~Hz}$ filter. Local coordinate systems for individual segments of the human body were created by means of calibration measurements in the upright standing posture. Three-dimensional angles were calculated for the ankle, knee and hip joints by means of the Xyz Cardan sequence of rotations. The angular velocity of individual joints was calculated as a firstorder derivation of angular displacement dependent on time. The net joint moment was calculated by the inverse dynamics method, normalized with respect to the body mass and expressed in the local coordination system of the proximal segment (Grood \& Suntay, 1983). The net joint power was calculated as the vector product of the net joint moment and angular velocity. Only data from the right lower limb in the sagittal plane were used. Temporal instants of the right and left heels at initial contact with the surface and at toe-off were determined from the records of the retro-reflective markers located on the feet (Stanhope, Kepple, McGuire, \& Roman, 1990). Consequently, the local minimum for the ground reaction force was detected in the right and left lower extremity (Figure 1). Dependent variables (maximum and minimum values of net joint power) were determined as the global maximum or minimum values of the net power curves of the ankle, knee and hip joints in intervals between the selected temporal instants (Figure 1) (Winter, Aftab, James, \& Sharon, 1990).

\section{Statistical analysis}

Statistical analysis was carried out in Statistica (SAS Institute Inc., USA). The Kolmogorov-Smirnov test showed the data to be normally distributed. Twoway within-subjects repeated measures ANOVA (factors - repetition and the testing day) was carried out. Mauchly's test of sphericity was also used; when it indicated a violation of sphericity $(p<.05)$, the degrees of freedom were adjusted using the Greenhouse-Geisser method. The intraclass correlation coefficient (ICC), the typical error and the confidence interval were used to evaluate the reliability of the peak net power measurement (Hopkins, 2000). The minimum detectable change was calculated according to the equation - typical error - 1.96 - square root of 2 (Haley \& Fragala-Pinkham, 2006). The sample size estimation for a longitudinal study with an equal-sized experimental group and control group was calculated according to the equation - 32 . squared typical error/[squared (effect of size) - standard deviation between the subjects of the measurement] (Hopkins, 2000; Hopkins, 2006). In addition, we created a norm for the monitored group - an interval of one standard deviation from the mean angle, angular velocity, net moment of force, and power measured during the course of the gait cycle (Chang, Davis, \& Hamill, 2007). Each subject was represented by an average curve of six trials ( 3 from the first and 3 from the second measurement day). Statistical significance was determined for all tests at the level $p<.05$.

\section{RESULTS}

Figures 2, 3 and 4 present the curves for angle, angular velocity, net moment of force and power in the ankle, knee and hip joints during the course of the gait cycle. Repeating the test on the same day and on the next measurement day did not have any effect on the net power measurement in the individual joints of the human body during gait, with the exception of the repetitions influencing the RH1 parameter (Table 1). Intraclass correlation coefficients ICC reached values in the range of .70 to .89 on the first day, from .69 to .86 on the second day, and from .67 to .83 in total (Table 2). Only parameter A1 on the second day reached a less than satisfactory ICC value (<.70) (Nunnally \& Bernstein, 1994). Coefficients of variation ranged from $8 \%$ to $17 \%$ for the $\mathrm{A} 2, \mathrm{~K} 3$ and $\mathrm{K} 4$ parameters, from $18 \%$ to $25 \%$ for the $\mathrm{A} 1, \mathrm{~K} 2$ and $\mathrm{H} 1$ parameters, and from $26 \%$ 

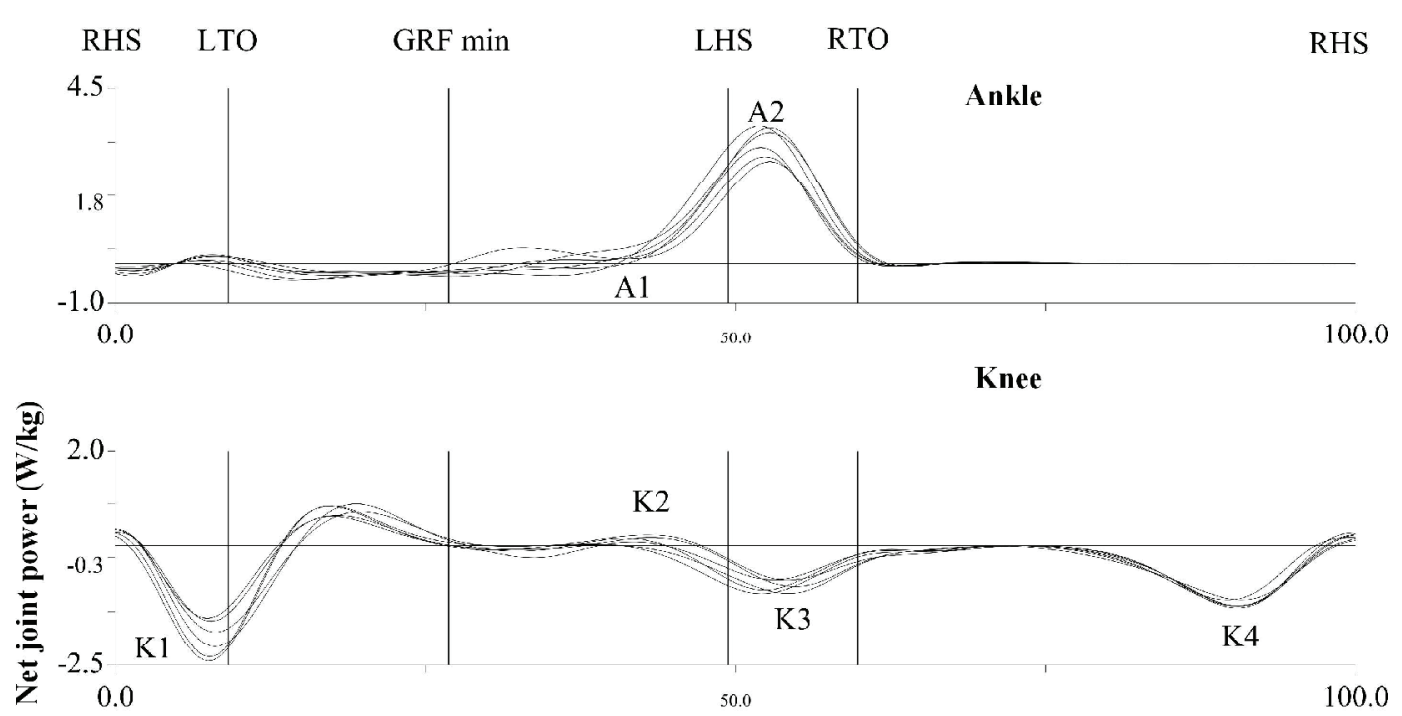

Hip

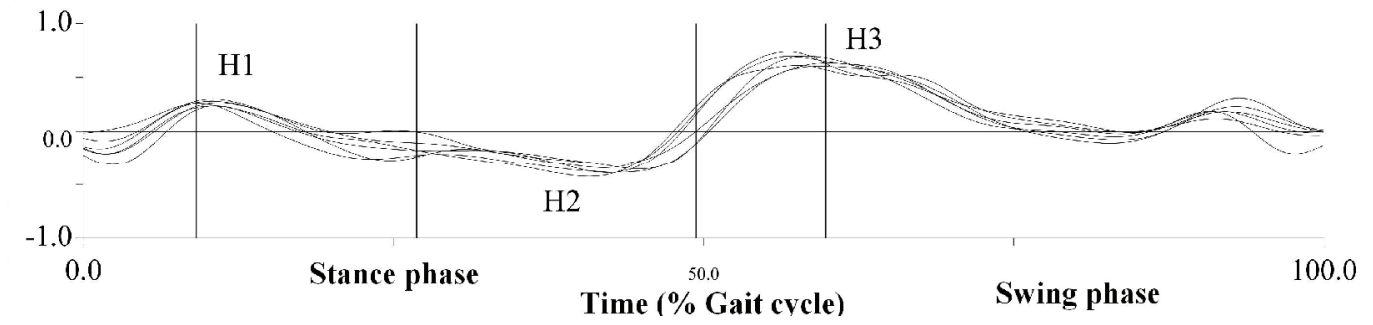

Figure 1. Net power in the right ankle, knee and hip joints of an able-bodied individual in relation to the relative time of the gait cycle. The graph records three trials from the first day and three trials from the second day of measurement $(N=6)$. RHS = contact of the right heel with the ground, LTO = left foot leaving the ground, LHS = contact of the left heel with the ground, RTO = right foot leaving the ground, GRF min.= local minimum of the ground reaction force in the right lower extremity, A1 = absorbed peak net ankle power between GRF min. and LHS, A2 = generated peak net ankle power in the upright posture of the right lower extremity between the instances RHS and RTO, $\mathrm{K} 1$ = absorbed peak net knee power between the instances RHS and LTO, K2 = generated peak net knee power between the instances GRF min. and LHS, K3 = absorbed peak net knee power between the instances LHS and RTO, $\mathrm{K} 4$ = absorbed peak net knee power in the swing phase of the right lower extremity between the instances RTO and RHS, H1 = generated peak net hip power between RHS and GRF min., H2 = absorbed peak net hip power between GRF min. and LTO, H3 = generated peak net hip power between LHS and RHS.

to $33 \%$ for the $\mathrm{K} 1, \mathrm{H} 2$ and $\mathrm{H} 3$ parameters. Minimal detectable change (MDC) calculated from the total typical error of measurement reached values ranging from $0.30 \mathrm{~W}$ to $0.97 \mathrm{~W}$ (Table 2). The estimate for the sample size of one experimental group for a longitudinal study with an equal-sized control group would reach values from 98 to 217 subjects for a small effect of size 0.2 (Cohen, 1988).

\section{DISCUSSION}

The average values of BMI, physical fat and physical activity of the monitored subjects oscillate within the range that was determined for healthy men of the same age (WHO, 1998). For the lower limb joints in young healthy men, the course of standard deviations for the net power in the sagittal plane corresponds to the graphs published by Sadeghi, Allard, and Duhaime (1997). Shape and range of the curves expressing the dependency of the angle, angular velocity, net moment of force and power on the time of the gait cycle in Figure 2, 3 and 4 are comparable with already published curves which are regarded as representative gait samples (Kirtley, 2006; Õunpuu, Davis, \& DeLuca, 1996; Perry, 1992; Whittle, 2007; Winter, Aftab, James, \& Sharon, 1990).

A change in the mean between the individual measurement days was not proved in any monitored parameter. For that reason we deduce that systematic errors of measurement, training or fatigue did not have any effect on the measurements. Only in the $\mathrm{H} 1$ parameter did the mean change in relation to the repetition regardless of the day of the measurement (Table 1). This 


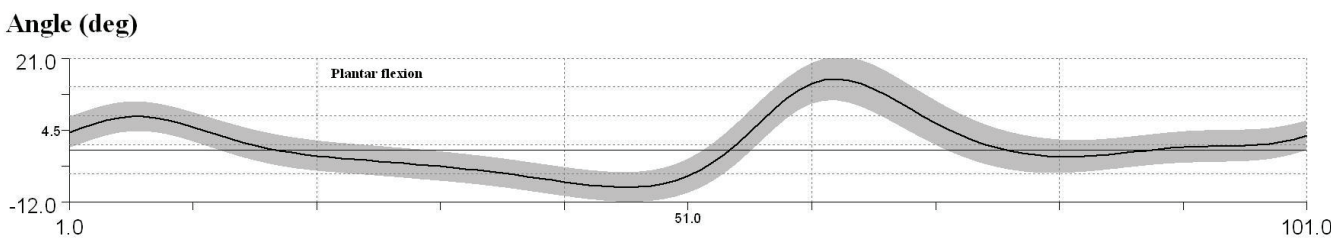

Angular velocity (deg/s)

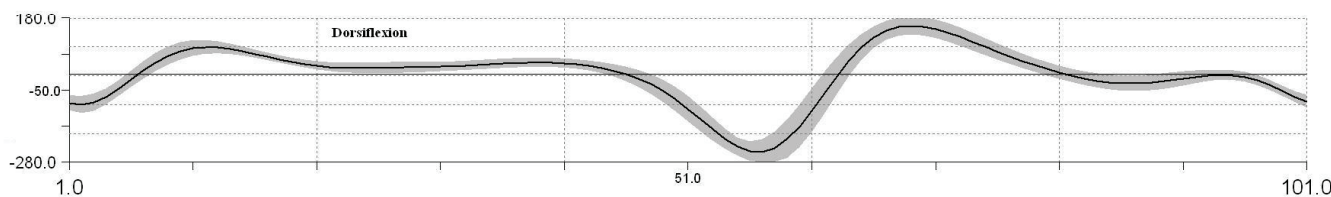

Moment of force $(\mathrm{Nm} / \mathrm{kg})$

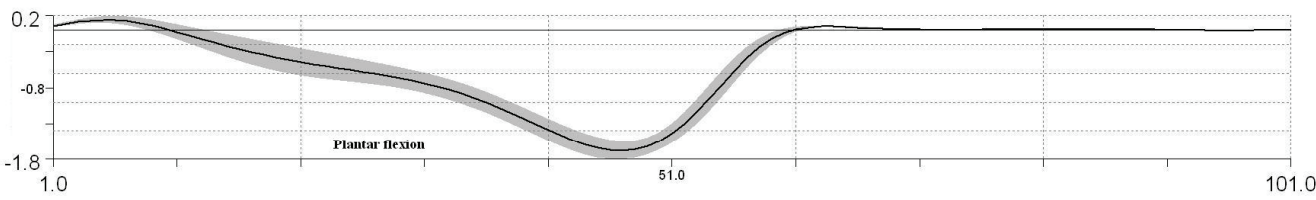

Net ankle power (W/kg)

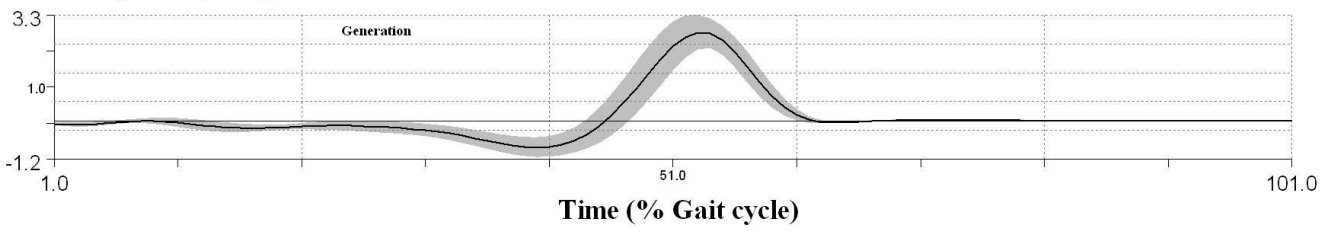

Figure 2. Average curves and intervals of standard deviations between the subjects for angle, angular velocity, net moment of force and power in the sagittal plane in the right ankle joint during the course of the gait cycle $(N=30)$

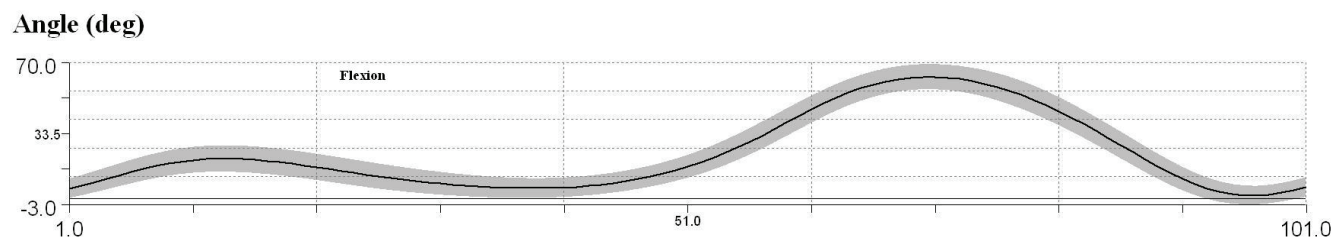

Angular velocity (deg/s)

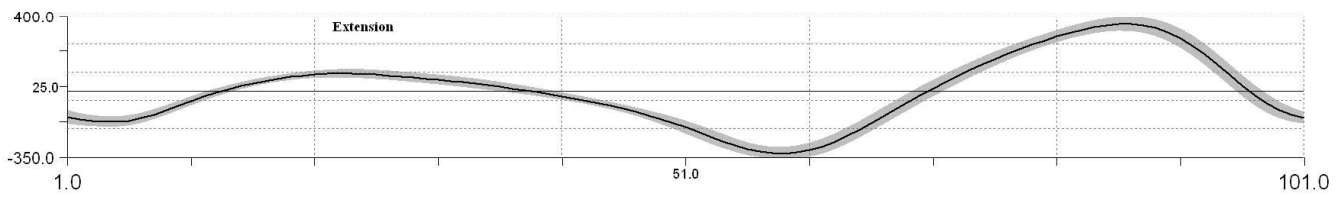

Moment of force $(\mathrm{Nm} / \mathrm{kg})$

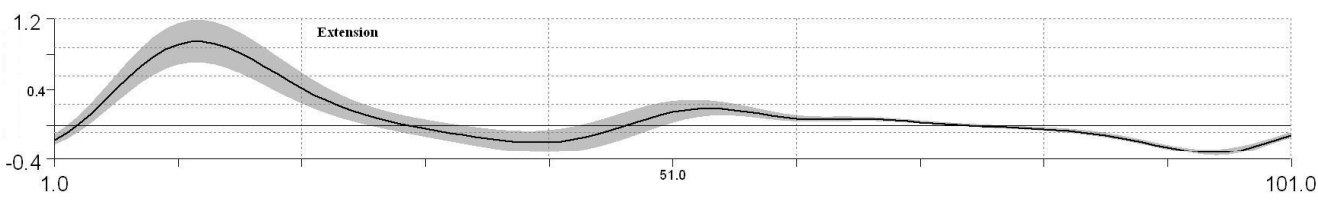

Net knee power (W/kg)

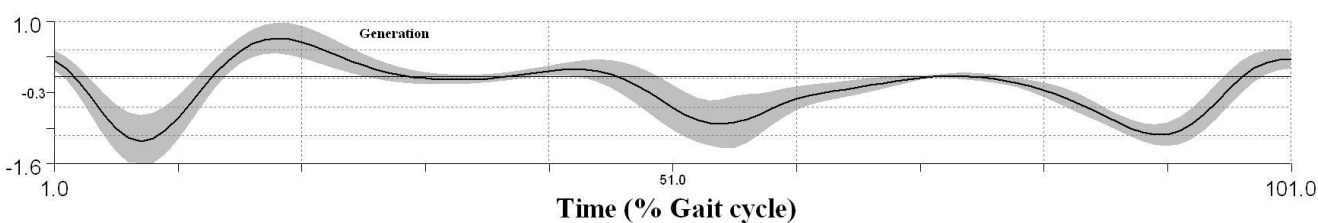

Figure 3. Average curves and intervals of standard deviations between the subjects for angle, angular velocity, net moment of force and power in the sagittal plane in the right knee joint during the course of the gait cycle $(N=30)$ 

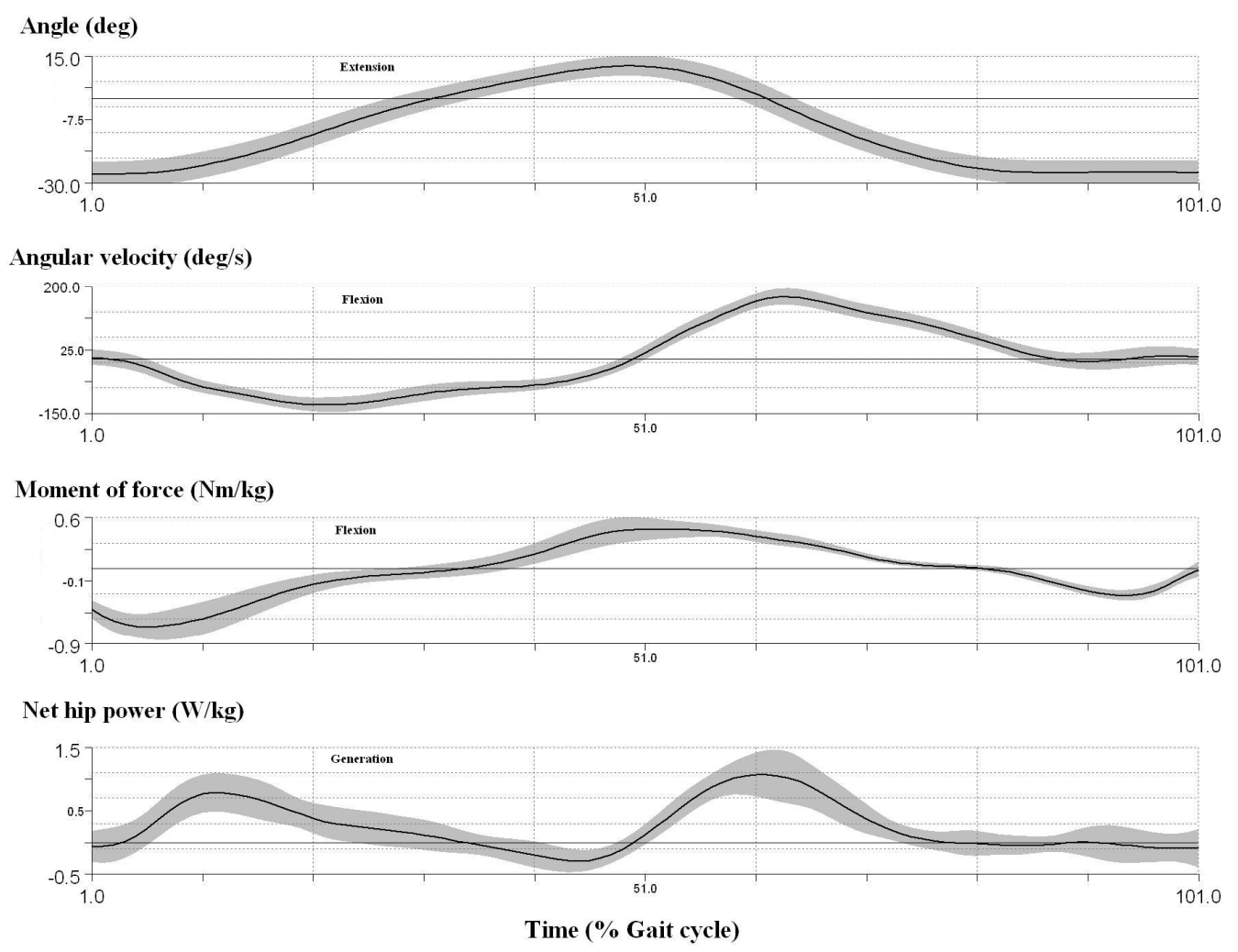

Figure 4. Average curves and intervals of standard deviations between the subjects for angle, angular velocity, net moment of force and power in the sagittal plane in the right hip joint during the course of the gait cycle $(N=30)$

might be explained as a consequence of the gradual decline in clusters on the thigh over the course of the measurements. Nevertheless, in such a case, repetitions would also influence the peak net powers $\mathrm{K} 1, \mathrm{~K} 2$, $\mathrm{K} 3, \mathrm{~K} 4, \mathrm{H} 2$ and $\mathrm{H} 3$ - and comparisons of these parameters did not confirm this (Table 1). In most cases, the relative reliability showed a generally satisfactory level (Nunnally \& Bernstein, 1994). The only exception was the peak absorption power in the ankle joint A1 (Table 2), which did not show sufficient reliability. Wilken, Rodriguez, Brawner, and Darter (2012) stated higher ICC values for the same peak power compared with the values measured in this study. The size of their group was comparable (29 subjects) but it was heterogeneous as it included both men and women. The increase in the ICC value may be caused by the heterogeneity of the group in the above-mentioned study.

The degree of reliability which is not influenced by the homogeneity of the group is the typical error of measurement (Hopkins, 2000). However, the concept of typical error of measurement is based on the presupposition of identical random error in all subjects (Hopkins, 2000). Manal, McClay, Stanhope, Richards, and Galinat (2000) showed that clusters with four markers reduce measurement errors caused by skin movements. Nevertheless, for example, retro-reflective markers on the pelvis are located directly on the skin, and women have higher amounts of subcutaneous fat (Bazzocchi et al., 2012). Heteroscedasticity of a mixed group of men and women could thus have affected the typical error in measurement and minimal detectable change (Haley \& Fragala-Pinkham, 2006). In our study with a homogeneous group, typical errors in measurement did not differ significantly between individual days and corresponded with the total typical error of measurement (Table 2). In the study by Wilken et al. (2012), the total typical error of measurement of the peak power ranged between 0.03 and $0.14 \mathrm{~W} / \mathrm{kg}$. The higher typical error of measurement recorded in our study could have been caused by the higher natural movement variability, which, in healthy persons, is associated with natural adaptation mechanisms against overloading (Bartlett, Wheat, \& Robins, 2007; Hamill, van Emmerik, Heiderscheit, \& Li, 1999).

In clinical practice or in case studies, it is suitable to apply minimal detectable change (Haley \& FragalaPinkham, 2006). The minimal detectable change in our study is higher than the minimal change occurring in consequence of the effect expressed according to Cohen (1988). This causes relatively large sample size estimation for longitudinal studies of a control group, calculated according to Hopkins $(2000,2006)$. 


\section{CONCLUSION}

This study presents the patterns of net power in the fundamental joints of the lower limbs in young healthy men at standard gait velocity. The reliability of the mea- surement of the peak net power within one day and between the two measurement days was evaluated as satisfactory (intraclass correlation coefficient $\geq 0.7$ ), with the exception of the absorbed peak net ankle power during stance phase. The study provides the values

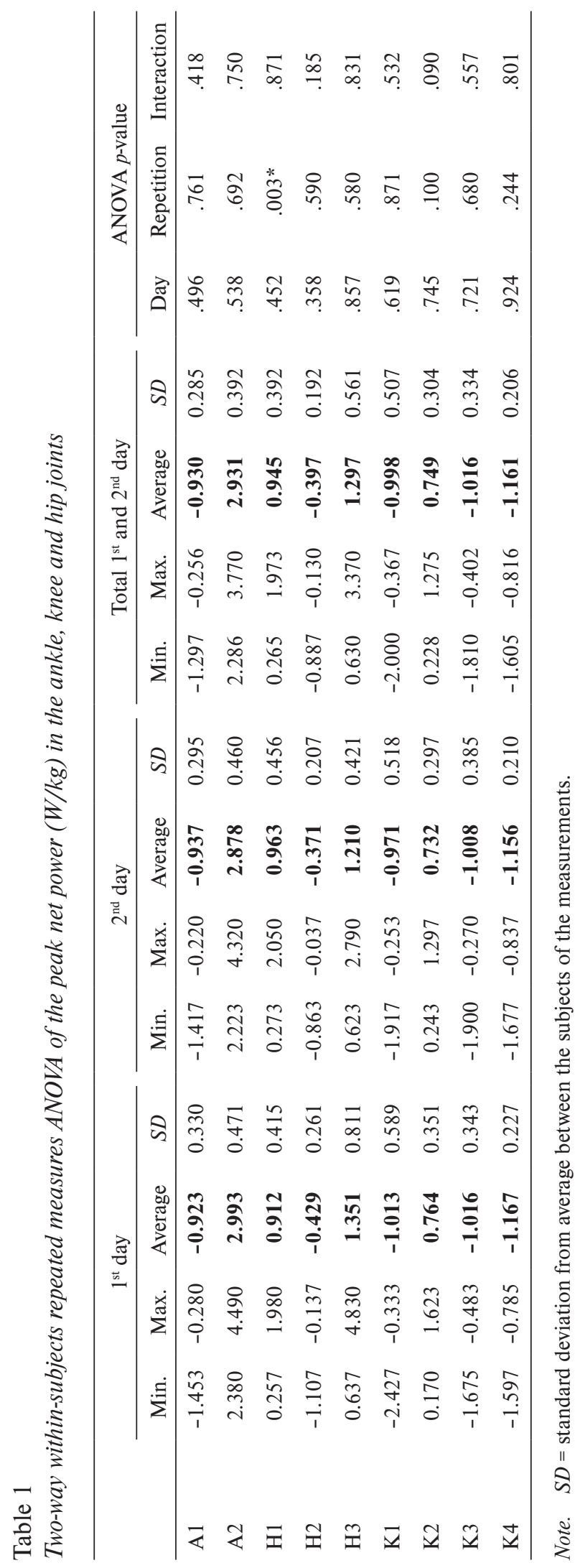


Table 2

Intra-class coefficient of correlation, typical error of measurement, confidence probability limits of typical error and minimal detectable change in repeated measurements of peak net power $(W / k g)$ in the ankle, knee and hip joints $(N=30)$

\begin{tabular}{|c|c|c|c|c|c|c|c|c|c|c|c|c|c|c|}
\hline & \multicolumn{4}{|c|}{$1^{\text {st }}$ day } & \multicolumn{4}{|c|}{$2^{\text {nd }}$ day } & \multicolumn{6}{|c|}{ Total $1^{\text {st }}$ and $2^{\text {nd }}$ day } \\
\hline & ICC & TE & $L L$ & $U L$ & ICC & $\mathrm{TE}$ & $L L$ & $U L$ & ICC & $\mathrm{TE}$ & $L L$ & $U L$ & MDC & $N$ \\
\hline A1 & .70 & 0.21 & 0.17 & 0.27 & .69 & 0.19 & 0.16 & 0.25 & .67 & 0.21 & 0.18 & 0.24 & 0.58 & 434 \\
\hline $\mathrm{A} 2$ & .78 & 0.24 & 0.19 & 0.30 & .78 & 0.24 & 0.20 & 0.30 & .74 & 0.25 & 0.22 & 0.30 & 0.69 & 325 \\
\hline $\mathrm{H} 1$ & .81 & 0.20 & 0.16 & 0.25 & .84 & 0.20 & 0.17 & 0.26 & .82 & 0.2 & 0.17 & 0.23 & 0.55 & 208 \\
\hline $\mathrm{H} 2$ & .77 & 0.14 & 0.12 & 0.18 & .82 & 0.10 & 0.08 & 0.13 & .73 & 0.13 & 0.12 & 0.16 & 0.36 & 367 \\
\hline H3 & .72 & 0.43 & 0.35 & 0.55 & .86 & 0.17 & 0.14 & 0.22 & .72 & 0.35 & 0.31 & 0.41 & 0.97 & 311 \\
\hline $\mathrm{K} 1$ & .81 & 0.29 & 0.24 & 0.37 & .77 & 0.28 & 0.24 & 0.36 & .77 & 0.30 & 0.27 & 0.35 & 0.83 & 280 \\
\hline $\mathrm{K} 2$ & .89 & 0.13 & 0.10 & 0.16 & .82 & 0.14 & 0.11 & 0.18 & .83 & 0.15 & 0.13 & 0.17 & 0.42 & 195 \\
\hline K3 & .82 & 0.16 & 0.14 & 0.21 & .82 & 0.17 & 0.14 & 0.22 & .80 & 0.18 & 0.16 & 0.21 & 0.50 & 232 \\
\hline K4 & .84 & 0.10 & 0.08 & 0.13 & .80 & 0.10 & 0.08 & 0.13 & .80 & 0.11 & 0.09 & 0.12 & 0.30 & 228 \\
\hline
\end{tabular}

Note. $\mathrm{ICC}=$ intra-class coefficient of correlation, $\mathrm{TE}=$ typical error of measurement, $L L=$ lower limit, $U L=$ upper limit, $\mathrm{MDC}=$ the minimal detectable change, $N=$ size of the group (experimental + control groups) when ES = 0.2.

of minimal detectable changes between the peak net powers of lower extremity joints in the sagittal plane during gait and sample size estimation. The net joint power appears to be reliable measure and could be used in practice.

\section{ACKNOWLEDGMENTS}

This research was supported by the Grant MSK Silesian Region of the Czech Republic (RRC/04/2009) and by the grant of the Ministry of Education, Youth and Sport of the Czech Republic (MSM 6198959221).

\section{REFERENCES}

Bartlett, R., Wheat, J., \& Robins, M. (2007). Is movement variability important for sports biomechanists? Sports Biomechanics, 6(2), 224-243.

Bazzocchi, A., Diano, D., Ponti, F., Andreone, A., Sassi, C., Albisinni, U., ... Battista, G. (2012). Health and ageing: A cross-sectional study of body composition. Clinical Nutrition, 32(4), 569-578.

Cappozzo, A., Croce, U. D., Leardini, A., \& Chiari, L. (2005). Human movement analysis using stereophotogrammetry (part 1): Theoretical background. Gait \& Posture, 21(2), 186-196.

Chang, R., Davis, I. S., \& Hamill, J. (2007). Rearfoot norms in a young, healthy population. Journal of Biomechanics, 40(2), 492.

Chen, I. H., Kuo, K. N., \& Andriacchi, T. P. (1997). The influence of walking speed on mechanical joint power during gait. Gait \& Posture, 3, 171-176.
Cohen, J. (1988). Statistical power analysis for the behavioral sciences. Hillsdale, NJ: Erlbaum.

Grood, E., \& Suntay, W. (1983). A joint coordinate system for the clinical description of three-dimensional motions: Application to the knee. Journal of Biomechanical Engineering, 105(2), 136-144.

Haley, S. M., \& Fragala-Pinkham, M. A. (2006). Interpreting change scores of tests and measures used in physical therapy. Physical Therapy, 86(5), 735-743.

Hamill, J., van Emmerik, R. E., Heiderscheit, B. C., \& Li, L. (1999). A dynamical systems approach to lower extremity running injuries. Clinical Biomechanics, 14, 297-308.

Hanavan, E. P. (1964). A mathematical model of the human body. Wright-Patterson Air Force Base, OH: Aerospace Medical Research Laboratory.

Hopkins, W. G. (2000). Measures of reliability in sports medicine and science. Sports Medicine, 30(1), 1-15.

Hopkins, W. G. (2006). Estimating sample size for magnitude-based inferences. Sportscience, 10, 6370.

Jandačka, D., Zahradník, D., Foldyna, K., \& Hamill, J. (2013). Running biomechanics in a long-term monitored recreational athlete with a history of Achilles tendon rupture. British Medical Journal Case Reports, 1-10. Retrieved from http://www.ncbi.nlm. nih.gov/pubmed/23362072

Kirtley, C. (2006). Clinical gait analysis. London: Churchill Livingstone.

Leardini, A., Chiari, L., Croce, U. D., \& Cappozzo, A. (2005). Human movement analysis using stereophotogrammetry (part 3): Soft tissue artifact assessment and compensation. Gait \& Posture, 21(2), 212-225. 
Manal, K., McClay, I., Stanhope, S., Richards, J., \& Galinat, B. (2000). Comparison of surface mounted markers and attachment methods in estimating tibial rotations during walking: An in vivo study. Gait \& Posture, 11(1), 38-45.

Nunnally, J. C., \& Bernstein, I. H. (1994). Psychometric theory (3rd ed.). New York, NY: McGraw-Hill.

Ounpuu, S., Davis, R. B., \& DeLuca, P. A. (1996). Joint kinetics: Methods, interpretation and treatment decision-making in children with cerebral palsy and myelomeningocele. Gait \& Posture, 4(1), 62-78.

Perry, J. (1992). Gait analysis: Normal and pathological function. Thorofare, NJ: SLACK Incorporated.

Sadeghi, H., Allard, P., \& Duhaime, M. (1997). Functional gait asymmetry in able-bodied subjects. $\mathrm{Hu}$ man Movement Science, 16, 243-258.

Sadeghi, H., Allard, P., Prince, F., \& Labelle, H. (2000). Symmetry and limb dominance in able-bodied gait: A review. Gait \& Posture, 12(1), 34-45.

Seeley, M. K., Umberger, B. R., \& Shapiro, R. (2008). A test of the functional asymmetry hypothesis in walking. Gait \& Posture, 28, 24-28.

Stanhope, S. J., Kepple, T. M., McGuire, D. A., \& Roman, N. L. (1990). A kinematic-based technique for event time determination during gait. Medical and Biological Engineering and Computing, 28, 355-360.

Svoboda, Z., Janura, M., Cabell, L., \& Elfmark, M. (2012). Variability of kinetic variables during gait in unilateral transtibial amputees. Prosthetics and Orthotics International, 36(2), 225-230.

Whittle, M. W. (2007). Gait analysis: An introduction. Philadelphia: Elsevier.

WHO. (1998). Obesity: Preventing and managing the global epidemic. In Report of a World Health $\mathrm{Or}$ ganization consultation on obesity. Geneva: World Health Organization.

Wilken, J. M., Rodriguez, K. M., Brawner, M., \& Darter, B. J. (2012). Reliability and minimal detectible change values for gait kinematics and kinetics in healthy adults. Gait Posture, 35(2), 301-307.

Winter, D., Aftab, E. P., James, S. F., \& Sharon, E. W. (1990). Biomechanical walking pattern changes in the fit and healthy elderly. Physical Therapy, 70(6), 340-347.

\section{TEST-RETEST SPOLEHLIVOST MĚŘENÍ VÝSTUPNÍHO VÝKONU KLOUBŮ DOLNÍCH KONČETIN P̌̌I CHŮZI ZDRAVÝCH MUŽŮ}

(Souhrn anglického textu)

CÍL: Stanovit reliabilitu měření výstupního výkonu dolních končetin při chůzi mezi opakovanými pokusy $\mathrm{v}$ rámci jednoho dne a mezi dvěma měřicími dny.

METODA: Studie se zúčastnilo třicet tělesně zdatných mužů. Podrobili se opakovanému měření biomechaniky chůze během každého ze dvou měřicích dní. K tomuto měření bylo použito 8 infračervených kamer a dvou silových plošin. Za platný byl označen pokus, ve kterém se rychlost chůze pohybovala v rozsahu $1,45 \mathrm{~m} / \mathrm{s} \pm 5 \%$. Byly stanoveny trojrozměrné úhly, úhlové rychlosti, výstupní momenty síly a výkony pro hlezenní, kolenní a kyčelní klouby.

VÝSLEDKY: Tato studie popisuje vzory výstupních výkonů kloubů dolních končetin u mladých zdravých mužů př̀ standardizované rychlosti chůze. Hodnoty vnitrotřídních korelačních koeficientů pro měření výstupního výkonu se první den pohybovaly v rozsahu od 0,70 do 0,89 , druhý den v rozsahu od 0,69 do 0,86 a celkově od 0,67 do 0,83 .

ZÁVĚR: Spolehlivost měření výstupního výkonu kloubů dolních končetin př́i chůzi byla ohodnocena jako uspokojivá jak v rámci jednoho dne, tak mezi jednotlivými dny. Tato studie poskytuje hodnoty minimální detekovatelné změny maxim a minim křivky výstupního výkonu stanovených v sagitální rovině při chůzi.

Klícová slova: analýza pohybu, inverzní dynamika, vnitrotřídní korelační koeficient, chyba měrení, minimální detekovatelná změna. 